\title{
Molecular Pathophysiology of Ossification of the Posterior Longitudinal Ligament (OPLL)
}

\author{
Dae Cheol Nam ${ }^{1, \dagger}$, Hyun Jae Lee ${ }^{2, \dagger}$, Choong Jae Lee ${ }^{3, *}$ and Sun-Chul Hwang ${ }^{1, *}$ \\ ${ }^{1}$ Department of Orthopaedic Surgery and Institute of Health Sciences, Gyeongsang National University School of Medicine and \\ Gyeongsang National University Hospital, Jinju 52727, \\ ${ }^{2}$ Smith Liberal Arts College and Department of Addiction Science, Graduate School, Sahmyook University, Seoul 01795, \\ ${ }^{3}$ Department of Pharmacology, School of Medicine, Chungnam National University, Daejeon 35015, Republic of Korea
}

\begin{abstract}
Ossification of the posterior longitudinal ligament (OPLL) can be defined as an ectopic ossification in the tissues of spinal ligament showing a hyperostotic condition. OPLL is developed mostly in the cervical spine and clinical presentations of OPLL are majorly myelopathy and/or radiculopathy, with serious neurological pathology resulting in paralysis of extremities and disturbances of motility lowering the quality of life. OPLL is known to be an idiopathic and multifactorial disease, which genetic factors and non-genetic factors including diet, obesity, physical strain on the posterior longitudinal ligament, age, and diabetes mellitus, are involved into the pathogenesis. Up to now, surgical management by decompressing the spinal cord is regarded as standard treatment for OPLL, although there might be the risk of development of reprogression of ossification. The molecular pathogenesis and efficient therapeutic strategy, especially pharmacotherapy and/or preventive intervention, of OPLL has not been clearly elucidated and suggested. Therefore, in this review, we tried to give an overview to the present research results on OPLL, in order to shed light on the potential pharmacotherapy based on molecular pathophysiologic aspect of OPLL, especially on the genetic/genomic factors involved into the etiology of OPLL.
\end{abstract}

Key Words: OPLL, Pathophysiology, Novel therapeutic approach

\section{INTRODUCTION}

Ossification of the posterior longitudinal ligament (OPLL) can be defined as an ectopic ossification (calcification) in the tissues of spinal ligament showing a hyperostotic condition (Matsunaga and Sakou, 2012; Kim et al., 2018). OPLL is developed mostly in the cervical spine (about 70\%), as well as in the thoracic and lumbar spine, predominantly in males (2 times more prevalent than in females) (Saetia et al., 2011; Kawaguchi et al., 2013). The clinical presentations of OPLL are majorly myelopathy and/or radiculopathy, with serious neurological pathology resulting in paralysis of extremities and disturbances of motility (motor function) lowering the quality of life. These manifestations are due to a reduction of volume of the spinal canal and the compression and injury of spinal cord by hardened ligament after ossification (Koyanagi et al., 2003; Chikuda et al., 2011; Kim et al., 2017). OPLL is known to be an idiopathic and multifactorial disease, which familial inheritance (genetic factors) and non-genetic factors including diet, obesity, physical strain on the posterior longitudinal ligament, age, and diabetes mellitus, are involved into the pathogenesis (Iwasaki et al., 2004; Kobashi et al., 2004; Stapleton et al., 2011; Ikegawa, 2014; Kawaguchi et al., 2016). A multitude of research on OPLL has been performed in Japan, since the prevalence of OPLL has been reported to be 2.0-4.0\% in Japan, $1.0-3.0 \%$ in other Asian countries including Korea and China, and $0.1-1.7 \%$ in North America and continental Europe (Mori et al., 2014; Yoshimura et al., 2014; Fujimori et al., 2015). To date, surgical management by decompressing the spinal cord is regarded as standard treatment for OPLL, although there might be the risk of development of reprogression of ossification (Abiola et al., 2016; Shin et al., 2017; Beom and Seo, 2018; Lee et al., 2018). At the same time, the molecular pathogenesis and efficient therapeutic strategy, especially

\section{Open Access https://doi.org/10.4062/biomolther.2019.043}

This is an Open Access article distributed under the terms of the Creative Commons Attribution Non-Commercial License (http://creativecommons.org/licenses/by-nc/4.0/) which permits unrestricted non-commercial use, distribution, and reproduction in any medium, provided the original work is properly cited.

Copyright $\odot 2019$ The Korean Society of Applied Pharmacology
Received Mar 8, 2019 Revised Mar 31, 2019 Accepted Apr 9, 2019 Published Online May 2, 2019

\section{*Corresponding Authors}

E-mail: hscspine@hanmail.net (Hwang SC), LCJ123@cnu.ac.kr (Lee CJ) Tel: +82-55-750-8102 (Hwang SC), +82-42-580-8255 (Lee CJ) Fax: +82-55-750-8104 (Hwang SC), +82-42-585-6627 (Lee CJ) ${ }^{\dagger}$ The first two authors contributed equally to this work. 
pharmacotherapy and/or preventive intervention, of OPLL has not been clearly elucidated and suggested. Therefore, in this review, we tried to give an overview to the present research results on OPLL, in order to shed light on the potential pharmacotherapy based on the molecular pathophysiologic aspect of OPLL, especially on the genetic/genomic factors involved into the etiology of OPLL.

\section{CURRENT SURGICAL AND PHARMACOLOGICAL MANAGEMENT OF OPLL}

\section{Surgical management of OPLL}

In the current medical practices, OPLL-induced myelopathy in the cervical spine is managed by anterior decompression or posterior decompression. The anterior decompression means that the operational removal of ossified lesion, via the anterior side of the spine. However, it is technically difficult, since the posterior longitudinal ligament exists in front of the spinal cord. Thus, the posterior approach is carried out to achieve the decompression of spinal cord, although the complications associated with decompression surgery including postoperative re-progression of ossification should be overcome (Zeidman et al., 1997; Shin et al., 2011, 2017; Beom and Seo, 2018; Lee et al., 2018).

\section{Pharmacological and non-surgical management of OPLL}

The current non-surgical management of OPLL consists of physical therapy, observation, and administration of oral analgesics (Matsunaga et al., 2004; Pham et al., 2011). Pain and numbness, the symptoms of OPLL, make the patients ask to resolve them promptly. This kind of neuropathic pain can be managed by pharmacotherapy. Nonsteroidal anti-inflammatory drugs (NSAIDs), opioids, antidepressants, local anesthetics, mecobalamin, and anticonvulsants have been utilized for controlling neuropathic pain (Furukawa, 2008; Tu et al., 2015; Liu et al., 2017). However, these drugs are used just for symptomatic relief. Therefore, the development of a novel agent for curing and/or preventing the myelopathy due to ossification of spinal ligament based upon targeting the molecular pathophysiology of OPLL is essentially required (Table 1).

\section{MOLECULAR PATHOPHYSIOLOGY OF OPLL}

The pathogenesis of OPLL has not been clearly understood. Although both genetic and environmental (non-genetic)

Table 1. The management of OPLL

\begin{tabular}{|c|c|}
\hline Surgical management & $\begin{array}{l}\text { Anterior decompression; } \\
\text { Operational removal of ossified } \\
\text { lesion via the anterior side of the } \\
\text { spine } \\
\text { Posterior decompression; } \\
\text { Posterior approach carried out } \\
\text { to achieve the decompression of } \\
\text { spinal cord }\end{array}$ \\
\hline $\begin{array}{l}\text { Pharmacological and } \\
\text { non-surgical management }\end{array}$ & $\begin{array}{l}\text { Physical therapy (and observation) } \\
\text { Administration of oral analgesics }\end{array}$ \\
\hline
\end{tabular}

factors are reported to be associated with the occurrence of OPLL, this disease shows an intense genetic predisposition (Wang et al., 1999; Okamoto et al., 2004; Furukawa, 2006; Ikegawa, 2014; Liang et al., 2018).

\section{Genetics of the susceptibility to OPLL}

A multitude of study found the associated genetic loci linked to susceptibility to OPLL. Karasugi et al. (2013) reported that OPLL-associated loci showing potential linkages at 20p12, $16 q 24,7 q 22,2 p 22-2 p 24$, and 1p21 were suggested as a result of a genome-wide linkage study using 214 siblings-pairs of OPLL. Also, 6p21.1, 8q23.1, 8q23.3, 12p11.22, 12p12.2, and 20p12.3 were identified as OPLL-susceptibility loci based on a result of a genome-wide association study (GWAS) (Nakajima et al., 2014). GWAS for OPLL provided substantial information on chromosomal positions associated with OPLL, although the causal genes of OPLL and functional genomic positions are required to be connected closely by the efficient target gene association studies. The prevalence of OPLL in cervical spine was $26.15 \%$ in the parents and $28.89 \%$ in the siblings of probands from 347 families with cervical OPLL, which are higher than those in the general population (Terayama, 1989). The siblings sharing identical human leukocyte antigen (HLA) haplotypes from families of 24 OPLL patients showed the higher prevalence of OPLL and a significant linkage on D6S276 with OPLL (Matsunaga et al., 1999). Tanaka et al. (2003) suggested that another potential genetic factor of OPLL, collagen 6A1 (COL6A1), exists on 21q (D21S1903). In cartilage and bone, the amount of transforming growth factor- $\beta$ (TGF- $\beta$ ) is relatively high and there are many target cells for TGF- $\beta$. By autocrine and paracrine secretions, TGF- $\beta$ plays a pivotal role in keeping and proliferating mesenchymal stem cells and progenitors of osteoblasts (Bonewald and Mundy, 1990; Chen et al., 2012). Therefore, the TGF- $\beta$ genes, especially TGF- $\beta 1$, are considered the major candidates promoting the susceptibility to OPLL, because of its significance in controlling bone metabolism (Bonewald and Dallas, 1994; Kamiya et al., 2001; Kawaguchi et al., 2003). It is known that the TGF- $\beta$ superfamily consists of TGF- $\beta$ s, Activin, bone morphogenetic proteins (BMPs) and Nodal, totally forty or more members. In mammalian development, intracellular signaling of TGF- $\beta$ /BMPs in concert with MAPK, FGF, Notch, Wnt, and Hedgehog signaling pathways are very important in the formation of bone (Chen et al., 2012). There are many reports on single nucleotide polymorphism (SNP) in TGF- $\beta$ genes and their significance in the prevalence of OPLL. However, to date, the results of the studies are not consistent and more investigations are needed for reaching the conclusion (Kamiya et al., 2001; Kawaguchi et al., 2003; Horikosi et al., 2006; Han et al., 2013; Jekarl et al., 2013). Collagen is known to play an important role during the development of cartilage and bone. Several genes encoding collagen, COL6A1, COL11A2, and COL17A1, have been reported to be associated with OPLL. Diverse pathological phenotypes of connective tissues might be provoked by aberrant expressions and/or mutations of collagen genes (Tsukahara et al., 2005; Kong et al., 2007; Kim et al., 2014). Similar to the case of TGF- $\beta$ genes, many studies on SNPs in genes of collagen and their association in the occurrence of OPLL have been performed. Some of them suggested that a specific gene is linked to the prevalence of OPLL, although the relevance of these SNPs of genes encoding collagen in the etiology of OPLL is still not obvious (Koga 
et al., 1998; Sakou et al., 2000; Maeda et al., 2001; Wei et al., 2014). Ectonucleotide Pyrophosphatase/Phosphodiesterase 1 (ENPP1) is a type II transmembrane metalloenzyme. It is known to control the calcification of soft tissue and bone, as an inhibitor of calcification by producing inorganic bisphosphate (PPi) (Sun and Mauerhan, 2012). An animal model for human OPLL, the tiptoe walking (twy) mice, shows a spontaneous development of abnormal ossification of the posterior longitudinal spinal ligament (Hosoda et al., 1981; Uchida et al., 2012). ENPP1 was reported to be the responsible gene for phenotypes of twy mice (Okawa et al., 1998). The four SNPs in ENPP1 have been reported to be linked to the development and/or severity of OPLL in humans (Koshizuka et al., 2002; Tahara et al., 2005; Horikoshi et al., 2006). He et al. (2013) reported that patients with a specific SNP in ENPP1 showed a good prognosis after surgery for decompression of the spinal cord. BMPs, a group of TGF- $\beta$ family, are known to induce the differentiation of chondrocytes and osteoblasts in the development of cartilage and bone. Intracellular signaling of Smad provoked by BMP has been known to regulate Msx2, Runx2, DIx5/6, Osterix and Sox9, the transcriptional factors required for the chondrogenesis and osteoblastogenesis (Marcellini et al., 2012; Shi et al., 2013; Rahman et al., 2015; Sanchez-Duffhues et al., 2015). In the tissues of ligament affected by OPLL, receptors for BMPs are expressed in higher levels than in the normal ligament tissues, suggesting that BMP might mediate the occurrence of OPLL (Yonemori et al., 1997). The SNPs in genes of BMPs have been studied in relation to the development of OPLL (Wang et al., 2018). A specific SNPs of BMP2 was found in the OPLL patients with higher rate than in the normal population (Wang et al., 2008; Yan et al., 2013; Li et al., 2014) and significantly linked to strengthened susceptibility to OPLL (Ren et al., 2012). Taken together, it is essentially required to characterize the SNPs in the ligament tissues of OPLL from the big size of samples systematically, since the majority of studies on various genes linked to susceptibility to OPLL have been based upon the small number of sequence variants and small sample sizes. Moreover, the evident functional relationship between the SNPs associated with OPLL and the progression and occurrence of the disease should be clarified through future study (Table 2).

\section{Physical stress and OPLL}

Interestingly, physical (mechanical) stress to the tissues of ligament, especially a cyclical stretch, has been reported to increase the expression levels of various genes including osteopontin, alkaline phosphatase (ALP), endothelin-1, BMP2, Type I collagen, Cbfa1 (an osteoblast-specific transcription

Table 2. The major genes associated with the susceptibility to OPLL

\begin{tabular}{l}
\hline Ectonucleotide Pyrophosphatase/Phosphodiesterase 1 \\
(ENPP1), Integrin $\beta 1$ \\
Transforming growth factor- $\beta 1$ (TGF- $\beta 1$ ), Endothelin-1 \\
Bone morphogenetic proteins (BMPs)-2, Bone morphogenetic \\
proteins (BMPs)-4 \\
COL6A1, COL11A2, and COL17A1, Type I collagen \\
Osteopontin, Alkaline phosphatase (ALP), Osteocalcin \\
Cbfa1 (an osteoblast-specific transcription factor), \\
BMP receptors \\
\hline
\end{tabular}

factor), BMP-4, osteocalcin, BMP receptors, and integrin $\beta 1$ and induce OPLL development and its progression (Iwasaki et al., 2004; Furukawa, 2006; Iwasawa et al., 2006). Physical stress also controlled the expression of a specific subtype of purinoceptors in OPLL cells and stimulated the progression of OPLL (Sawada et al., 2008). Ohishi et al. (2003) reported that the synthesis of prostaglandin in the cells of ligament of OPLL patients increased by physical stress and it stimulated the differentiation of osteoblasts. Overexpression of vimentin, one of the filament proteins, in osteoblasts was reported to inhibit the differentiation of osteoblasts resulting in suppression of mineralization. Physical stress decreased the expression level of vimentin and stimulated the progression of OPLL (Shapiro et al., 1995; Zhang et al., 2014). Physical stress increased the expression level of connexin 43 (Cx43, gap junction alpha-1 protein), the protein provoking OPLL, via p38 MAPK and ERK signaling pathway in spinal ligament fibroblasts from OPLL patients (Yang et al., 2011; Chen et al., 2014, 2016).

\section{Biomarkers of OPLL}

Serum levels of insulin, leptin, and osteocalcin, a bone-formation marker, are positively associated with the occurrence of OPLL (Akune et al., 2001; Sugimori et al., 2003; Ikeda et al., 2011). In the ligaments of OPLL, the levels of nebulin-related anchoring protein and osteoglycin increased, while those of biliverdin reductase $B$, alpha-1 collagen $\mathrm{VI}, \mathrm{NAD}(\mathrm{P})$ dependent steroid dehydrogenase-like, and carbonic anhydrase I decreased (Zhang et al., 2015). Sclerostin and dickkopf-1 (DKK1) are known to exert a significant activity on the formation of bone and sclerostin levels in serum are higher in the male OPLL patients than those in the normal people (Morvan et al., 2006; Modder et al., 2011; Szulc et al., 2013). It was reported that serum levels of DKK1 were negatively correlated in the patients with OPLL (Kashii et al., 2016). Also, the serum levels of osteocalcin and carboxyterminal propeptide of human type 1 procollagen (PICP) are higher in patients with OPLL than in normal people (Matsui et al., 1996) (Table 3).

\section{OPLL and mesenchymal stem cells (MSCs)}

MSCs are defined as multipotent progenitor cells differentiating to diverse types of cells, including chondrocytes and osteoblasts. MSCs derived from spinal ligaments may differentiate to chondrogenic, adipogenic, or osteogenic cells and play a pivotal role in abnormal ossification process (Asari et al., 2012; Medici and Olsen, 2012; Nelson et al., 2012; Nomura et al., 2013). The transcription factors including Runx2, Sox9, Osterix, and Msx2 have been reported to control chondrogenesis and osteogenesis from MSCs (Nishimura et al., 2012). Also, the expression levels of parathyroid-related peptide hormone (PTHrP), Sox9, and Indian hedgehog (Ihh) in

Table 3. The Biomarkers of OPLL

\begin{tabular}{cc}
\hline $\begin{array}{c}\text { Positively } \\
\text { associated } \\
\text { biomarkers }\end{array}$ & $\begin{array}{c}\text { Insulin, Leptin, Osteocalcin, Osteoglycin, } \\
\text { Nebulin-related anchoring protein, }\end{array}$ \\
Negatively & Biliverdin reductase B, Dickkopf-1 \\
associated & (DKK1), Carbonic anhydrase I, Alpha-1 \\
biomarkers & $\begin{array}{c}\text { collagen VI, NAD }(P) \text { dependent steroid } \\
\text { dehydrogenase-like }\end{array}$ \\
\hline
\end{tabular}




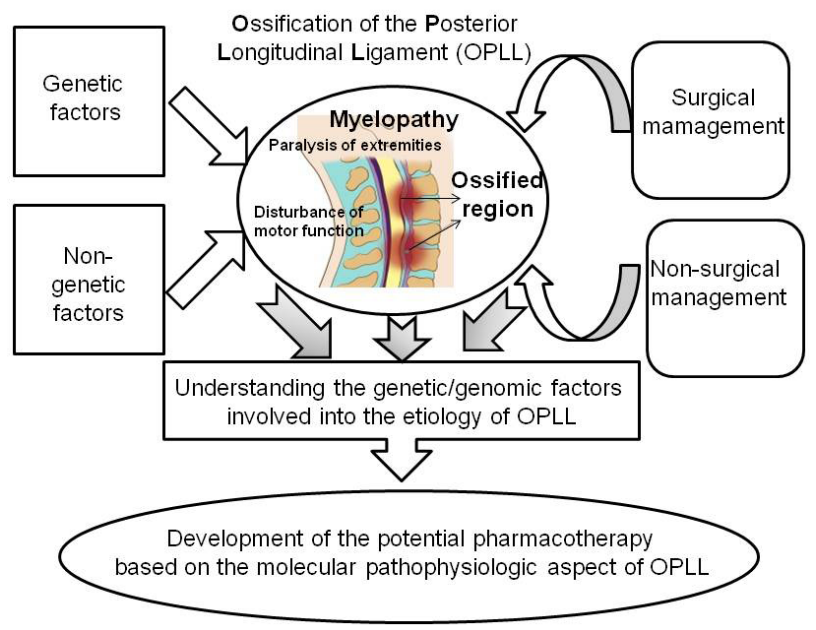

Fig. 1. Overview of etiology, management, and strategy for the development of potential pharmacotherapy.

the tissues of OPLL were reported to be increased than in the normal ligament tissues (Sugita et al., 2013). Therefore, through future investigations, it is urgently needed to elucidate the exact role of aberrant intracellular signaling in MSCs derived from spinal ligament, during the process of development and progression of OPLL.

\section{OPLL and dietary factors}

Up to now, there are few reports on the relationship between dietary habits and the development of OPLL. Wang et al. (1999) reported that, in Taiwan, a high-salt diet through intaking much amount of pickled foods and low intake of meat daily are positively associated with the occurrence of OPLL. Okamoto and his colleagues also reported that, in Japan, frequent intake of chicken and soy foods and frequent consumption of pickles were associated negatively and positively with the development of OPLL, respectively (Okamoto et al., 2004). The exact relationship between diets and the occurrence of OPLL is unclear because of the limited results of existing investigational studies. More and more extensive investigations are urgently needed for elucidating the relationship between dietary habits and the risk of development of OPLL.

\section{CONCLUSION AND FUTURE DIRECTION FOR OPLL RESEARCH}

In spite of a multitude of investigations, the exact causal genes for the development of OPLL are still not elucidated, although diverse genes showed the evidence of being involved into the occurrence and progression of OPLL. In addition to the current surgical management of OPLL, cutting-edge strategy for prevention and management using pharmacological means is essentially needed and has not been suggested until now. Therefore, novel drugs and/or drug targets should be developed based on the in-depth additional examination of genetic factors involved into the etiology of OPLL. Specifically, novel agents that can possibly regulate the intracellular signaling of TGF- $\beta /$ BMPs and/or the genes encoding collagen, which is known to play an important role during the develop- ment of bone and to be associated with OPLL, including COL6A1, COL11A2, and COL17A1, should be developed. Also, the environmental factors, especially the exact relationship between diets and the occurrence of OPLL, should be specified through future investigational studies (Fig. 1).

\section{CONFLICT OF INTEREST}

The authors have no conflict of interest to declare.

\section{ACKNOWLEDGMENTS}

This research was supported by NRF-2014R1A6A1029617 and NRF-2017R1C1B1005126, Basic Science Research Program through the National Research Foundation of Korea (NRF) funded by the Ministry of Education.

\section{REFERENCES}

Abiola, R., Rubery, P. and Mesfin, A. (2016) Ossification of the posterior longitudinal ligament: etiology, diagnosis, and outcomes of nonoperative and operative management. Global Spine J. 6, 195-204.

Akune, T., Ogata, N., Seichi, A., Ohnishi, I., Nakamura, K. and Kawaguchi, H. (2001) Insulin secretory response is positively associated with the extent of ossification of the posterior longitudinal ligament of the spine. J. Bone Joint Surg. Am. 83-A, 1537-1544.

Asari, T., Furukawa, K., Tanaka, S., Kudo, H., Mizukami, H., Ono, A., Numasawa, T., Kumagai, G., Motomura, S., Yagihashi, S. and Toh, S. (2012) Mesenchymal stem cell isolation and characterization from human spinal ligaments. Biochem. Biophys. Res. Commun. 417, 1193-1199.

Beom, J. Y. and Seo, H. Y. (2018) the need for early tracheostomy in patients with traumatic cervical cord injury. Clin. Orthop. Surg. 10, 191-196.

Bonewald, L. F. and Dallas, S. L. (1994) Role of active and latent transforming growth factor beta in bone formation. J. Cell. Biochem. 55, 350-357.

Bonewald, L. F. and Mundy, G. R. (1990) Role of transforming growth factor-beta in bone remodeling. Clin. Orthop. Relat. Res. 250, 261 276.

Chen, D., Liu, Y., Yang, H., Chen, D., Zhang, X., Fermandes, J. C. and Chen, Y. (2016) Connexin 43 promotes ossification of the posterior longitudinal ligament through activation of the ERK1/2 and p38 MAPK pathways. Cell Tissue Res. 363, 765-773.

Chen, G., Deng, C. and Li, Y.P. (2012) TGF-beta and BMP signaling in osteoblast differentiation and bone formation. Int. J. Biol. Sci. 8 , 272-288.

Chen, Y., Wang, X., Yang, H., Miao, J., Liu, X. and Chen, D. (2014) Upregulated expression of PERK in spinal ligament fibroblasts from the patients with ossification of the posterior longitudinal ligament Eur. Spine J. 23, 447-454

Chikuda, H., Seichi, A. and Takeshita, K. (2011) Acute cervical spinal cord injury complicated by preexisting ossification of the posterior longitudinal ligament: a multicenter study. Spine 36, 1453-1458.

Fujimori, T., Le, H., Hu, S.S., Chin, C., Pekmezci, M., Schairer, W., Tay, B. K., Hamasaki, T., Yoshikawa, H. and Iwasaki, M. (2015) Ossification of the posterior longitudinal ligament of the cervical spine in 3161 patients: a CT-based study. Spine 40, E394-E403.

Furukawa, K. (2006) Current topics in pharmacological research on bone metabolism: molecular basis of ectopic bone formation induced by mechanical stress. J. Pharmacol. Sci. 100, 201-204

Furukawa, K. (2008) Pharmacological aspect of ectopic ossification in spinal ligament tissues. Pharmacol. Ther. 118, 352-358.

Han, I. B., Ropper, A. E., Jeon, Y. J., Park, H. S., Shin, D. A., Teng, Y. D., Kuh, S. U. and Kim, N. K. (2013) Association of transforming growth factor-beta 1 gene polymorphism with genetic susceptibil- 
ity to ossification of the posterior longitudinal ligament in Korean patients. Genet. Mol. Res. 12, 4807-4816.

He, Z., Zhu, H., Ding, L., Xiao, H., Chen, D. and Xue, F. (2013) Association of NPP1 polymorphism with postoperative progression of ossification of the posterior longitudinal ligament in Chinese patients. Genet. Mol. Res. 12, 4648-4655.

Horikoshi, T., Maeda, K., Kawaguchi, Y., Chiba, K., Mori, K., Koshizuka, Y., Hirabayashi, S., Sugimori, K., Matsumoto, M., Kawaguchi, H., Takahashi, M., Inoue, H., Kimura, T., Matsusue, Y., Inoue, I., Baba, H., Nakamura, K. and Ikegawa, S. (2006) A large-scale genetic association study of ossification of the posterior longitudinal ligament of the spine. Hum Genet. 119, 611-616.

Hosoda, Y., Yoshimura, Y. and Higaki, S. (1981) A new breed of mouse showing multiple osteochondral lesions - twy mouse. Ryumachi 21 Suppl, 157-164.

Ikeda, Y., Nakajima, A., Aiba, A., Koda, M., Okawa, A., Takahashi, K. and Yamazaki, M. (2011) Association between serum leptin and bone metabolic markers, and the development of heterotopic ossification of the spinal ligament in female patients with ossification of the posterior longitudinal ligament. Eur. Spine J. 20, 1450-1458.

Ikegawa, S. (2014) Genomic study of ossification of the posterior longitudinal ligament of the spine. Proc. Jpn. Acad. Ser. B. Phys. Biol. Sci. 90, 405-412.

Iwasaki, K., Furukawa, K. I., Tanno, M., Kusumi, T., Ueyama, K., Tanaka, M., Kudo, H., Toh, S., Harata, S. and Motomura, S. (2004) Uni-axial cyclic stretch induces Cbfa1 expression in spinal ligament cells derived from patients with ossification of the posterior longitudinal ligament. Calcif. Tissue Int. 74, 448-457.

Iwasawa, T., Iwasaki, K., Sawada, T., Okada, A., Ueyama, K., Motomura, S., Harata, S., Inoue, I., Toh, S. and Furukawa, K. I. (2006) Pathophysiological role of endothelin in ectopic ossification of human spinal ligaments induced by mechanical stress. Calcif. Tissue Int. 79, 422-430.

Jekarl, D. W., Paek, C. M., An, Y. J., Kim, Y. J., Kim, M., Kim, Y., Lee, J. and Sung, C. H. (2013) TGFBR2 gene polymorphism is associated with ossification of the posterior longitudinal ligament. J. Clin. Neurosci. 20, 453-456.

Kamiya, M., Harada, A., Mizuno, M., Iwata, H. and Yamada, Y. (2001) Association between a polymorphism of the transforming growth factor-beta1 gene and genetic susceptibility to ossification of the posterior longitudinal ligament in Japanese patients. Spine 26, 1264-1266.

Karasugi, T., Nakajima, M., Ikari, K.; Genetic Study Group of Investigation Committee on Ossification of the Spinal Ligaments, Tsuji, T., Matsumoto, M., Chiba, K., Uchida, K., Kawaguchi, Y., Mizuta, H., Ogata, N., Iwasaki, M., Maeda, S., Numasawa, T., Abumi, K., Kato, T., Ozawa, H., Taguchi, T., Kaito, T., Neo, M., Yamazaki, M., Tadokoro, N., Yoshida, M., Nakahara, S., Endo, K., Imagama, S., Demura, S., Sato, K., Seichi, A., Ichimura, S., Watanabe, M., Watanabe, K., Nakamura, Y., Mori, K., Baba, H., Toyama, Y. and Ikegawa, S. (2013) A genome-wide sib-pair linkage analysis of ossification of the posterior longitudinal ligament of the spine. J. Bone Miner. Metab. 31, 136-143.

Kashii, M., Matuso, Y., Sugiura, T., Fujimori, T., Nagamoto, Y., Makino, T., Kaito, T., Ebina, K., Iwasaki, M. and Yoshikawa, H. (2016) Circulating sclerostin and dickkopf-1 levels in ossification of the posterior longitudinal ligament of the spine. J. Bone Miner. Metab. 34, 315-324.

Kawaguchi, Y., Furushima, K., Sugimori, K., Inoue, I. and Kimura, T. (2003) Association between polymorphism of the transforming growth factor-beta1 gene with the radiologic characteristic and ossification of the posterior longitudinal ligament. Spine 28, 14241426.

Kawaguchi, Y., Nakano, M., Yasuda, T., Seki, S., Hori, T. and Kimura, T. (2013) Ossification of the posterior longitudinal ligament in not only the cervical spine, but also other spinal regions: analysis using multidetector computed tomography of the whole spine. Spine 38, E1477-E1482.

Kawaguchi, Y., Nakano, M., Yasuda, T., Seki, S., Hori, T., Suzuki, K., Makino, H. and Kimura, T. (2016) Characteristics of ossification of the spinal ligament; incidence of ossification of the ligamentum flavum in patients with cervical ossification of the posterior longitudi- nal ligament - analysis of the whole spine using multidetector CT. J. Orthop. Sci. 21, 439-445.

Kim, B. S., Moon, M. S., Yoon, M. G., Kim, S. T., Kim, S. J., Kim, M. S. and Kim, D. S. (2018) Prevalence of diffuse idiopathic skeletal hyperostosis diagnosed by whole spine computed tomography: a preliminary study. Clin. Orthop. Surg. 10, 41-46.

Kim, K. H., Kuh, S. U., Park, J. Y., Lee, S. J., Park, H. S., Chin, D. K., Kim, K. S. and Cho, Y. E. (2014) Association between BMP-2 and COL6A1 gene polymorphisms with susceptibility to ossification of the posterior longitudinal ligament of the cervical spine in Korean patients and family members. Genet. Mol. Res. 13, 2240-2247.

Kim, Y. H., Ha, K. Y. and Kim, S. I. (2017) Spinal cord injury and related clinical trials. Clin. Orthop. Surg. 9, 1-9.

Kobashi, G., Washio, M., Okamoto, K., Sasaki, S., Yokoyama, T., Miyake, Y., Sakamoto, N., Ohta, K., Inaba, Y. and Tanaka, H.; Japan Collaborative Epidemiological Study Group for Evaluation of Ossification of the Posterior Longitudinal Ligament of the Spine Risk. (2004) High body mass index after age 20 and diabetes mellitus are independent risk factors for ossification of the posterior longitudinal ligament of the spine in Japanese subjects: a case-control study in multiple hospitals. Spine 29, 1006-1010.

Koga, H., Sakou, T., Taketomi, E., Hayashi, K., Numasawa, T., Harata, S., Yone, K., Matsunaga, S., Otterud, B., Inoue, I. and Leppert, M. (1998) Genetic mapping of ossification of the posterior longitudinal ligament of the spine. Am. J. Hum. Genet. 62, 1460-1467.

Kong, Q., Ma, X., Li, F., Guo, Z., Qi, Q., Li, W., Yuan, H., Wang, Z. and Chen, Z. (2007) COL6A1 polymorphisms associated with ossification of the ligamentum flavum and ossification of the posterior longitudinal ligament. Spine 32, 2834-2838.

Koshizuka, Y., Kawaguchi, H., Ogata, N., Ikeda, T., Mabuchi, A., Seichi, A., Nakamura, Y., Nakamura, K. and Ikegawa, S. (2002) Nucleotide pyrophosphatase gene polymorphism associated with ossification of the posterior longitudinal ligament of the spine. $J$. Bone. Miner. Res. 17, 138-144.

Koyanagi, I., Iwasaki, Y., Hida, K., Imamura, H., Fujimoto, S. and Akino, M. (2003) Acute cervical cord injury associated with ossification of the posterior longitudinal ligament. Neurosurgery 53, 887-892.

Lee, D. Y., Park, Y. J., Song, S. Y., Hwang, S. C., Kim, K. T. and Kim D. H. (2018) The importance of early surgical decompression for acute traumatic spinal cord injury. Clin. Orthop. Surg. 10, 448-454.

Li, J. M., Zhang, Y., Ren, Y., Liu, B. G., Lin, X., Yang, J., Zhao, H. C., Wang, Y. J. and Song, L. (2014) Uniaxial cyclic stretch promotes osteogenic differentiation and synthesis of BMP2 in the C3H10T1/2 cells with BMP2 gene variant of rs2273073 (T/G). PLOS ONE 9 , e106598.

Liang, C., Wang, P., Liu, X., Yang, C., Ma, Y., Yong, L., Zhu, B., Liu, X. and Liu, Z. (2018) Whole-genome sequencing reveals novel genes in ossification of the posterior longitudinal ligament of the thoracic spine in the Chinese population. J. Orthop. Surg. Res. 13, 324.

Liu, X., Kumagai, G., Wada, K., Tanaka, T., Fujita, T., Sasaki, A., Furukawa, K. I. and Ishibashi, Y. (2017) Suppression of osteogenic differentiation in mesenchymal stem cells from patients with ossification of the posterior longitudinal ligament by a histamine-2-receptor antagonist. Eur. J. Pharmacol. 810, 156-162.

Maeda, S., Ishidou, Y., Koga, H, Taketomi, E., Ikari, K., Komiya, S., Takeda, J., Sakou, T. and Inoue, I. (2001) Functional impact of human collagen alpha2 (XI) gene polymorphism in pathogenesis of ossification of the posterior longitudinal ligament of the spine. $J$. Bone Miner. Res. 16, 948-957.

Marcellini, S., Henriquez, J. P. and Bertin, A. (2012) Control of osteogenesis by the canonical Wnt and BMP pathways in vivo: cooperation and antagonism between the canonical Wnt and BMP pathways as cells differentiate from osteochondroprogenitors to osteoblasts and osteocytes. BioEssays 34, 953-962.

Matsui, H., Yudoh, K. and Tsuji, H. (1996) Significance of serum levels of type I procollagen peptide and intact osteocalcin and bone mineral density in patients with ossification of the posterior longitudinal ligaments. Calcif. Tissue Int. 59, 397-400.

Matsunaga, S., Sakou, T., Taketomi, E. and Komiya, S. (2004) Clinical course of patients with ossification of the posterior longitudina ligament: a minimum 10-year cohort study. J. Neurosurg. 100, 245248 . 
Matsunaga, S. and Sakou, T. (2012) Ossification of the posterior longitudinal ligament of the cervical spine: etiology and natural history. Spine 37, E309-E314.

Matsunaga, S., Yamaguchi, M., Hayashi, K. and Sakou, T. (1999) Genetic analysis of ossification of the posterior longitudinal ligament. Spine 24, 937-939.

Medici, D. and Olsen, B. R. (2012) The role of endothelial-mesenchymal transition in heterotopic ossification. J. Bone Miner. Res. 27, 1619-1622.

Modder, U. I., Clowes, J. A., Hoey, K., Peterson, J. M., McCready, L., Oursler, M. J., Riggs, B. L. and Khosla, S. (2011) Regulation of circulating sclerostin levels by sex steroids in women and in men. J. Bone Miner. Res. 26, 27-34.

Mori, K., Imai, S., Kasahara, T., Nishizawa, K., Mimura, T. and Matsusue, Y. (2014) Prevalence, distribution, and morphology of thoracic ossification of the posterior longitudinal ligament in japanese: results of CT-based cross-sectional study. Spine 39, 394-399.

Morvan, F., Boulukos, K., Clement-Lacroix, P., Roman, R. S, Suc-Royer, I., Vayssiere, B., Ammann, P., Martin, P., Pinho, S., Pognonec, P., Mollat, P., Niehrs, C., Baron, R. and Rawadi, G. (2006) Deletion of a single allele of the Dkk1 gene leads to an increase in bone formation and bone mass. J. Bone Miner. Res. 21, 934-945

Nakajima, M., Takahashi, A., Tsuji, T., Karasugi, T., Baba, H., Uchida, K., Kawabata, S., Okawa, A., Shindo, S., Takeuchi, K., Taniguchi, Y., Maeda, S., Kashii, M., Seichi, A., Nakajima, H., Kawaguchi, Y., Fujibayashi, S., Takahata, M., Tanaka, T., Watanabe, K., Kida, K., Kanchiku, T., Ito, Z., Mori, K., Kaito, T., Kobayashi, S., Yamada, K., Takahashi, M., Chiba, K., Matsumoto, M., Furukawa, K., Kubo, M., Toyama, Y.; Genetic Study Group of Investigation Committee on Ossification of the Spinal Ligaments and Ikegawa, S. (2014) A genome-wide association study identifies susceptibility loci for ossification of the posterior longitudinal ligament of the spine. Nat. Genet. 46, 1012-1016.

Nelson, E. R., Wong, V. W., Krebsbach, P. H., Wang, S. C. and Levi, B. (2012) Heterotopic ossification following burn injury: the role of stem cells. J. Burn. Care. Res. 33, 463-470.

Nishimura, R., Hata, K., Matsubara, T., Wakabayashi, M. and Yoneda, T. (2012) Regulation of bone and cartilage development by network between BMP signalling and transcription factors. J. Biochem. 151, 247-254.

Nomura, A., Seya, K., Yu, Z., Daitoku, K., Motomura, S., Murakami, M., Fukuda, I. and Furukawa, K. (2013) CD34-negative mesenchymal stem-like cells may act as the cellular origin of human aortic valve calcification. Biochem. Biophys. Res. Commun. 440, 780-785.

Ohishi, H., Furukawa, K., Iwasaki, K., Ueyama, K., Okada, A., Motomura, S., Harata, S. and Toh, S. (2003) Role of prostaglandin 12 in the gene expression induced by mechanical stress in spinal ligament cells derived from patients with ossification of the posterior longitudinal ligament. J. Pharmacol. Exp. Ther. 305, 818-824.

Okamoto, K., Kobashi, G., Washio, M., Sasaki, S., Yokoyama, T., Miyake, Y., Sakamoto, N., Ohta, K., Inaba, Y. and Tanaka, H.; Japan Collaborative Epidemiological Study Group for Evaluation of Ossification of the Posterior Longitudinal Ligament of the Spine (OPLL) Risk. (2004) Dietary habits and risk of ossification of the posterior longitudinal ligaments of the spine (OPLL); findings from a casecontrol study in Japan. J. Bone Miner. Metab. 22, 612-617.

Okawa, A., Nakamura, I., Goto, S., Moriya, H., Nakamura, Y. and lkegawa, S. (1998) Mutation in Npps in a mouse model of ossification of the posterior longitudinal ligament of the spine. Nat. Genet. 19, 271-273.

Pham, M. H., Attenello, F. J., Lucas, J., He, S., Stapleton, C. J. and Hsieh, P. C. (2011) Conservative management of ossification of the posterior longitudinal ligament. A review. Neurosurg. Focus 30, E2.

Rahman, M. S., Akhtar, N., Jamil, H. M., Banik, R. S. and Asaduzzaman, S. M. (2015) TGF-beta/BMP signaling and other molecular events: regulation of osteoblastogenesis and bone formation. Bone Res. 3, 15005.

Ren, Y., Liu, Z. Z., Feng, J., Wan, H., Li, J. H., Wang, H. and Lin, X. (2012) Association of a BMP9 haplotype with ossification of the posterior longitudinal ligament (OPLL) in a Chinese population. PLOS ONE 7, e40587.

Saetia, K., Cho, D., Lee, S., Kim, D. H. and Kim, S. D. (2011) Ossifi- cation of the posterior longitudinal ligament: a review. Neurosurg. Focus 30, E1.

Sakou, T., Matsunaga, S. and Koga, H. (2000) Recent progress in the study of pathogenesis of ossification of the posterior longitudinal ligament. J. Orthop. Sci. 5, 310-315.

Sanchez-Duffhues, G., Hiepen, C., Knaus, P. and Ten Dijke, P. (2015) Bone morphogenetic protein signaling in bone homeostasis. Bone 80, 43-59.

Sawada, T., Kishiya, M., Kanemaru, K., Seya, K., Yokoyama, T., Ueyama, K., Motomura, S., Toh, S. and Furukawa, K. (2008) Possible role of extracellular nucleotides in ectopic ossification of human spinal ligaments. J. Pharmacol. Sci. 106, 152-161.

Shapiro, F., Cahill, C., Malatantis, G. and Nayak, R. C. (1995) Transmission electron microscopic demonstration of vimentin in rat osteoblast and osteocyte cell bodies and processes using the immunogold technique. Anat. Rec. 241, 39-48.

Shi, S., de Gorter, D. J., Hoogaars W. M., Hoen, P. A. and Ten Dijke, P. (2013) Overactive bone morphogenetic protein signaling in heterotopic ossification and Duchenne muscular dystrophy. Cell Mol. Life Sc. 70, 407-423.

Shin, H. K., Jeong, H. J., Kim, E., Park, J. H, Park, S. J. and Cho, Y. (2017) Should we check the routine postoperative MRI for hematoma in spinal decompression surgery? Clin. Orthop. Surg. $\mathbf{9}$ 184-189.

Shin, J. H., Steinmetz, M. P., Benzel, E. C. and Krishnaney, A. A. (2011) Dorsal versus ventral surgery for cervical ossification of the posterior longitudinal ligament: considerations for approach selection and review of surgical outcomes. Neurosurg. Focus 30, E8.

Stapleton, C. J., Pham, M. H., Attenello, F. J. and Hsieh, P. C. (2011) Ossification of the posterior longitudinal ligament: genetics and pathophysiology. Neurosurg. Focus 30, E6.

Sugimori, K., Kawaguchi, Y., Ohmori, K., Kanamori M., Ishihara, H. and Kimura, T. (2003) Significance of bone formation markers in patients with ossification of the posterior longitudinal ligament of the spine. Spine 28, 378-379.

Sugita, D., Yayama, T., Uchida, K., Kokubo, Y., Nakajima, H., Yamagishi, A., Takeura, N. and Baba, H. (2013) Indian hedgehog signaling promotes chondrocyte differentiation in enchondral ossification in human cervical ossification of the posterior longitudinal ligament. Spine 38, E1388-E1396.

Sun, Y. and Mauerhan, D. R. (2012) Meniscal calcification, pathogenesis and implications. Curr. Opin. Rheumatol. 24, 152-157.

Szulc, P., Boutroy, S., Vilayphiou, N., Schoppet, M., Rauner, M., Chapurlat, R., Hamann, C. and Hofbauer, L. C. (2013) Correlates of bone microarchitectural parameters and serum sclerostin levels in men: the STRAMBO study. J. Bone Miner. Res. 28, 1760-1770.

Tahara, M., Aiba, A., Yamazaki, M., Ikeda, Y, Goto, S., Moriya, H. and Okawa, A. (2005) The extent of ossification of posterior longitudinal ligament of the spine associated with nucleotide pyrophosphatase gene and leptin receptor gene polymorphisms. Spine 30, 877-881.

Tanaka, T., Ikari, K., Furushima, K., Okada, A., Tanaka, H., Furukawa, K., Yoshida, K., Ikeda, T., Ikegawa, S., Hunt, S. C., Takeda, J. Toh, S., Harata, S., Nakajima, T. and Inoue, I. (2003) Genomewide linkage and linkage disequilibrium analyses identify COL6A1, on chromosome 21, as the locus for ossification of the posterior longitudinal ligament of the spine. Am. J. Hum. Genet. 73, 812-822.

Terayama, K. (1989) Genetic studies on ossification of the posterior longitudinal ligament of the spine. Spine 14, 1184-1191.

Tsukahara, S., Miyazawa, N., Akagawa, H., Forejtova, S., Pavelka, K., Tanaka, T., Toh, S., Tajima, A., Akiyama, I. and Inoue, I. (2005) COL6A1, the candidate gene for ossification of the posterior longitudinal ligament, is associated with diffuse idiopathic skeletal hyperostosis in Japanese. Spine 30, 2321-2324.

Tu, T. H., Wu, J. C., Huang, W. C., Chang, H. K., Ko, C. C., Fay, L. Y., Wu, C. L. and Cheng, H. (2015) Postoperative nonsteroidal antiinflammatory drugs and the prevention of heterotopic ossification after cervical arthroplasty: analysis using CT and a minimum 2-year follow-up. J. Neurosurg. Spine 22, 447-453.

Uchida, K., Yayama, T., Sugita, D., Nakajima, H., Rodriguez Guerrero, A., Watanabe, S., Roberts, S., Johnson, W. E. and Baba, H. (2012 Initiation and progression of ossification of the posterior longitudinal ligament of the cervical spine in the hereditary spinal hyperos- 
totic mouse (twy/twy). Eur. Spine J. 21, 149-155.

Wang, H., Jin, W. and Li, H. (2018) Genetic polymorphisms in bone morphogenetic protein receptor type IA gene predisposes individuals to ossification of the posterior longitudinal ligament of the cervical spine via the smad signaling pathway. BMC Musculoskelet. Disord. 19, 61.

Wang, H., Liu, D., Yang, Z., Tian, B., Li, J., Meng, X., Wang, Z., Yang, $H$. and Lin, X. (2008) Association of bone morphogenetic protein-2 gene polymorphisms with susceptibility to ossification of the posterior longitudinal ligament of the spine and its severity in Chinese patients. Eur. Spine J. 17, 956-964.

Wang, P. N., Chen, S. S., Liu, H. C., Fuh, J. L., Kuo, B. I. and Wang, S. J. (1999) Ossification of the posterior longitudinal ligament of the spine. A case-control risk factor study. Spine 24, 142-144.

Wei, W., He, H. L., Chen, C. Y., Zhao, Y., Jiang, H. L., Liu, W. T., Du, Z. F., Chen, X. L., Shi, S. Y. and Zhang, X. N. (2014) Whole exome sequencing implicates PTCH1 and COL17A1 genes in ossification of the posterior longitudinal ligament of the cervical spine in Chinese patients. Genet. Mol. Res. 13, 1794-1804.

Yan, L., Chang, Z., Liu, Y., Li, Y. B., He, B. R. and Hao, D. J. (2013) A single nucleotide polymorphism in the human bone morphogenetic protein-2 gene (109T > G) affects the Smad signaling pathway and the predisposition to ossification of the posterior longitudinal ligament of the spine. Chin. Med. J. 126, 1112-1118.

Yang, H. S., Lu, X. H., Chen, D. Y., Yuan, W., Yang, L. L., Chen, Y. and He, H. L. (2011) Mechanical strain induces Cx43 expression in spinal ligament fibroblasts derived from patients presenting ossification of the posterior longitudinal ligament. Eur. Spine J. 20, 1459-1465.

Yonemori, K., Imamura, T., Ishidou, Y., Okano, T., Matsunaga, S., Yoshida, H., Kato, M., Sampath, T. K., Miyazono, K., ten Dijke, P. and Sakou, T. (1997) Bone morphogenetic protein receptors and activin receptors are highly expressed in ossified ligament tissues of patients with ossification of the posterior longitudinal ligament. Am. J. Pathol. 150, 1335-1347.

Yoshimura, N., Nagata, K., Muraki, S., Oka, H., Yoshida, M., Enyo, Y., Kagotani, R., Hashizume, H., Yamada, H., Ishimoto, Y., Teraguchi, M., Tanaka, S., Kawaguchi, H., Toyama, Y., Nakamura, K. and Akune, T. (2014) Prevalence and progression of radiographic ossification of the posterior longitudinal ligament and associated factors in the Japanese population: a 3-year follow-up of the ROAD study. Osteoporos. Int. 25, 1089-1098.

Zeidman, S. M., Ducker, T. B. and Raycroft, J. (1997) Trends and complications in cervical spine surgery: 1989-1993. J. Spinal Disord. 10, 523-526.

Zhang, W., Wei, P., Chen, Y., Yang, L., Jiang, C., Jiang, P. and Chen, D. (2014) Down-regulated expression of vimentin induced by mechanical stress in fibroblasts derived from patients with ossification of the posterior longitudinal ligament. Eur. Spine J. 23, 2410-2415.

Zhang, Y, Liu, B., Shao, J., Song, J. and Zhang, J. (2015) Proteomic profiling of posterior longitudinal ligament of cervical spine. Int. J. Clin. Exp. Med. 8, 5631-5639. 